\title{
A Review on Biosurfactants and its Environmental Applications
}

\author{
C.Vigneshwaran, M.Jerold, K.Vasantharaj, V. Sivasubramanian,* \\ Department of Chemical Engineering, National Institute of Technology Calicut, Kozhikode - 673 601, Kerala, \\ India \\ *E-mail: siva@nitc.ac.in
}

\begin{abstract}
Biosurfactants are widely known as surface active agents of biological origin. Glycolipid classes of biosurfactants has high important in the biotechnological arena. Pseudomonas aeruginosa, Bacillus subtilis, and Candida sp., are important classes of microorganism and highly investigated for the production of glycolipid biosurfactants. Commercially, microbial biosurfactants are more advantageous than chemical based biosurfactants due to their biodegradability, renewability and functionality maintenance under extreme operating conditions. In the oil spill areas hydrocarbon degrading microorganisms (isolated) were proven to produce enormous amount of biosurfactant than expected. This is due to the regulation of all the genomes in the synthesis of lipid metabolism. Currently, biosurfactants play vital role in oil and petroleum industries for emulsification in both recovery and removal process from the site of pollution. In addition, it has some role in the heavy metal removal of metallurgical industries. In the present paper, we have given the overview on screening of biosurfactant producing microorganisms, production methods and factors influencing the production of biosurfactants are investigated. Various analytical techniques used for processing of crude metabolites are also presented. Thus from this review, can easily understood the role of biosurfactant in the environmental cleaning.
\end{abstract}

Keywords: Biosurfactants, Emulsification, Environmental cleaning, Hydrocarbon

\section{Introduction}

Biosurfactants are surface active compounds produced by microorganism which have indispensible environmental applications. There are different groups of biosurfactants in the form of glycolipid, phospolipid and lipopeptide. The glycolipid biosurfactants containing sugar molecule and hydroxyl fatty acids were found to have hydrophilic and hydrophobic activities. The later type was reported to have some functional roles such as surfactant, emulsifier and bioactive. Generally, biological surfactants are highly biodegradable, non-toxic and renewable and may perform over synthetic surfactants with high surface tension, interfacial tension and critical micelle concentration. These can be produced easily in a short interval of time. Biological surfactants have excellent detergent, foaming, wetting, and micro-emulsifying properties ${ }^{1}$. It can be operated at high $\mathrm{pH}$, salinity and temperature ${ }^{2}$. Generally, a surfactant can reduce the surface tension of water to $25-40 \mathrm{mN} / \mathrm{m}$ and having critical micelle concentration value of 5-380 mg/l. Similarly interfacial tension decreases in oil and water to < 1 dyne/cm. Pseudomonas aeruginosa is a special microorganism for the production of biosurfactants because of its ability to degrade wide variety of substrates. Cheap raw materials used for the biosurfactant production are oil waste, soap stock and other waste from food industries and vegetable oil refineries. Amongst the entire carbon sources, vegetable based oil is found to have higher biosurfactant yield ${ }^{3}$.

Moreover, the properties of biosourfactants are similar to each other. However, glycolipid biosurfactants were reported as promising biosurfactants with various advantages. Some of these advantages are environmental remediations, non-toxic and biodegradable. There are wide applications of biosurfactants in various sectors such as pharmaceuticals, therapeutics, cosmetics, detergents, agriculture and removal of heavy metals and in oil recovery ${ }^{4}$.

\section{General Classification of Biosurfactants}

Chemically synthesized surfactants are usually classified depending on the nature of their polar groups. Normally they are categorized mainly by their chemical composition obtained by the different molecules forming the hydrophobic and hydrophilic moieties and microbial origin. The compositions of hydrophilic moiety are amino acids, peptides, mono, di, or polysaccharides and that of hydrophobic moiety are saturated or unsaturated fatty acids ${ }^{2}$. Rosenberg and Ron $^{5}$ suggested that biosurfactants can be classified into a lowmolecular-mass molecules, which mainly lower surface and interfacial tension, and high molecular-mass polymers, which are effective emulsion stabilizing agents. The major classes of low mass surfactants include glycolipids, lipopeptides and phospholipids, whereas high mass surfactants include polymeric and particulate surfactants like polyanionic hetero-polysaccharides containing both polysaccharides and proteins. The microbial 
surfactant production varies according to the nutritional environment of the growing microorganism. The most important types of biosurfactants are listed in Table 1.

Table 1: Type of Biosurfactants and Micro-organism Involved

\begin{tabular}{|l|l|}
\hline Types of Microbial Surfactants & Organisms involved \\
\hline Glycolipids & $\begin{array}{l}\text { Serratia marcescens, Alcanivorax borkumensis, Arthrobacter sp., } \\
\text { corynebacterium sp., }\end{array}$ \\
\hline Rhamnolipids & Pseudomonas sp., Pseudomonas aeruginosa, Serratia rubidea \\
\hline Sophorolipids & $\begin{array}{l}\text { Torulopsis apicola, T. bombicola } \\
\text { T. petrophilium, Candida apicola, Candida bombicola, Candida bogoriensis, } \\
\text { Candida lipolytica }\end{array}$ \\
\hline Trehalose lipids & $\begin{array}{l}\text { Rhodococcus erythropolis, Nocardia erythropolis, Mycobacterium sp., } \\
\text { Arthrobacter paraffineus, Corynebacterium sp }\end{array}$ \\
\hline $\begin{array}{l}\text { Fatty Acids (Spiculisporic Acids, } \\
\text { Corynomycolic Acids, etc., }\end{array}$ & $\begin{array}{l}\text { Candida lepus, Capnocytophaga sp., Corynebacterium lepus, Penicillium } \\
\text { spiculisporum, Norcadia erythropolis }\end{array}$ \\
\hline Carbohydrate-lipid-protein & Pseudomonas fluorescens \\
\hline Mannan-lipid-protein & Candida tropicalis \\
\hline Particulate Surfactants & Pseudomonas marginalis \\
\hline
\end{tabular}

\section{Mechanism of Hydrocarbon Utilization}

Although the actual uptake of alkanes by bacteria is thought to be a passive transport process, microorganism possesses a number of adaptive mechanisms for accumulating and transporting hydrocarbons into the cell for initial enzymatic catabolism ${ }^{6}$. Bacteria can transport and assimilate soluble alkanes that are dissolved in the aqueous phase. Indeed, it was initially thought that bacteria could utilize only solubilised hydrocarbon $^{7}$. However, alkanes are degraded at rates which exceed the rates of dissolution of hydrocarbon in the aqueous phase, indicating that other uptake mechanism are also utilized by hydrocarbon degrading microorganism ${ }^{8}$. Different mechanisms for the uptake of aliphatic hydrocarbons have been proposed. Due to the low solubility of long chain alkanes, a transport through the water phase in a dissolved state was ruled out ${ }^{9}$. The following steps are found to occur during the uptake of hydrocarbon a) small hydrocarbon droplets (micelles) are enclosed into the cells. b) The direct contact of cells to the bigger hydrocarbon phase enables the cells to enclose hydrocarbon into their cells.

Ron and Rosenberg ${ }^{10}$ reported that hydrocarbon degrading microorganism adapted to grow in oil containing environment have an important role in the biological treatment of the pollution. One of the limiting factors in this process especially at low temperature is the bioavailability of many fractions of the oil. The hydrocarbon degrading microorganisms produce biosurfactants of diverse chemical nature and molecular size.

\section{Screening of Microorganism}

Isolation of the strains from their natural habitats is the initial step in the selection stage. Followed by isolation, screening of specific microorganism for the production of desired product plays a significant role in the bio-processing of microbial cultures. A set of highly selective procedures, which allows the detection and isolation of microorganisms producing the desired metabolite, constitutes primary screening. Ideally, primary screening should be rapid, inexpensive, predictive, specific but effective for a broad range of compounds and applicable on a large scale. Primary screening is time-consuming and labour intensive since a large number of isolates have to be screened to identify a few potential ones. The various screening methods adopted for bioprocessing of biosurfactant producing microorganism are briefly discussed below.

Hydrocarbon overlay agar test is one of the efficient method in which the colonies formed in oil coated agar plates are surrounded by emulsified halo zones. The zone indicates that the microorganisms in the colonies utilizes hydrocarbons through biosurfactant production and hence a potential biosurfactant producers ${ }^{11}$. If the biosurfactant produced is categorized as rhamnolipids, then CTAB agar plate is the suitable screening method. In this method, the anionic biosurfactant forms insoluble ion pair with cationic CTAB-MB present in the medium and hence a dark blue halo zone is produced around the colonies ${ }^{12}$. Haemolytic activity is another screening method in which the rupture of red blood cells is identified in the presence of biosurfactants. However this method is an unreliable criterion for the detection of biosurfactant activity ${ }^{13}$.A simple method called drop collapse method is also widely used for screening biosurfactant producing organisms. The collapse in the pennzoil (hydrocarbon source) is noted for the presence of biosurfactants ${ }^{14}$. If the biosurfactant concentration is very low, this method gives negative results ${ }^{15}$.

Emulsification activity is one of an important parameter to evaluate biosurfactant producing microorganisms. The first approach of emulsification activity through optical density is developed by Rosenberg et $a l^{16}$ and later modified by Neu and Poralla ${ }^{17}$ Here, the optical density of culture broth added with hydrocarbon is compared with that of culture broth alone and the difference of which yields the emulsification activity. Another approach of emulsification activity is achieved through emulsification index. An emulsion layer formed between aqueous and kerosene layer is calculated and utilized for emulsification index. Emulsification index stability gives the knowledge on the strength of biosurfactant ${ }^{18,19}$. 


\section{Biosurfactant Production}

Many researchers employed various kinds of bacteria in producing biosurfactant using culture media. Most of the bacteria used are isolated from contaminated sites usually containing petroleum hydrocarbon byproducts and industrial wastes ${ }^{20}$.

\subsection{Fermentation Strategies for Biosurfactant Production}

Various fermentation strategies are adopted for the production of biosurfactant. In general the following are used in the rhamnolipid production such as shake flask, batch, fed-batch, continuous and integrated microbial/enzymatic process. In addition genetic engineering and immobilised cultivation are followed to enhance the surfactin production. Rhamnolipid is a secondary metabolite produced under growth limiting condition. However carbon source is excluded out of growth limiting substrate. In the production of rhamnolipid $\mathrm{N}$ and $\mathrm{P}$ are highly limited compound. However nitrogen source in the form of nitrate shown to increase biosurfactant production. The main carbon sources used for rhamnolipid production are glucose, glycerol, n-alkanes, ethanol and glycerolipids. Ammonia, urea, complex amino acid containing supplement were used as nitrogen sources ${ }^{21}$. In batch cultivation, growth limiting substrates such as plant oil or glucose are used for biosurfactant production. However in glycerol or plant oil serves as a growth limiting substrate for fed batch cultivation. In continuous cultivation mode glucose and hydrocarbon are used as substrates. Camilos-Neto et $a l^{22}$ reported about the application of solid state cultivation in continuous fermentation process. Cooper $e t a l^{23}$ reported glucose as a substrate for the production of surfactin, where the product is separated from the reactor by foam fractionation. Noah $e t \mathrm{al}^{24}$ studied the application of chemostat with stirred tank reactors for the production of surfactin using Bacillus subtilis. Airlift fermentor with continuous collection of foam was used to produce surfactin from Bacillus subtilis using potato process effluent as carbon source. Subsequently Yeh et $a l^{25}$ developed a novel bioreactor to avoid the foam spillage during the production of biosurfactant. The application of bubbleless bioreactor using a hollow fiber membrane as an air-liquid contactor was reported to produce surfactin and fengycin by Bacillus subtilis ${ }^{26}$.

\subsection{Factors Affecting The Biosurfactant Production}

In the production of biosurfactant various factors affect the yield as shown in Table 2. Some of the important factors are discussed below.

Table 2: Influence of Various Factors on Biosurfactant Production

\begin{tabular}{|c|c|c|c|c|c|c|c|}
\hline S.NO & Microorganism & Biosurfactant & pH & Temp. & Carbon source & Yield & References \\
\hline 1. & Bacillus brevis & & 8 & $33^{\circ} \mathrm{C}$ & $8.5 \mathrm{~g} / 1$ of glucose & - & 44 \\
\hline 2. & Pleurotus djamor & Lipopeptide & 5.5 & $29^{\circ} \mathrm{C}$ & $\begin{array}{c}5 \mathrm{~g} / \mathrm{l} \text { of sunflower } \\
\text { seed shell }\end{array}$ & $8.9 \pm 0.5 \mathrm{~g} / 1$ & 45 \\
\hline 3. & $\begin{array}{c}\text { Pseudomonas aeruginosa } \\
\text { KVD-HR42 }\end{array}$ & Rhamnolipids & 7.8 & $37^{\circ} \mathrm{C}$ & $23.85 \mathrm{~g} / 1$ karanja oil & $5.90 \pm 2.1 \mathrm{~g} / 1$ & 46 \\
\hline 4. & Bacillus ICA 56 & & 8.0 & & $\begin{array}{l}\text { Glycerol and } \\
\text { sunflower oil }\end{array}$ & $1290 \mathrm{mg} / 1$ & 47 \\
\hline 5. & $\begin{array}{c}\text { Pseudomonas aeruginosa } \\
\text { F23 }\end{array}$ & Rhamnolipids & 8 & $30^{\circ} \mathrm{C}$ & $1 \%$ coconut oil & $2.8 \mathrm{~g} / 1$ & 48 \\
\hline
\end{tabular}

\subsubsection{Effect of Carbon Sources}

Microbes used in the biosurfactant production utilise variety of carbon sources and energy for their growth. Pseudomonas aeruginosa utilises water soluble carbon source such as glycerol, mannitol, glucose and ethanol for rhamnolipid production ${ }^{27}$. Among the different carbon sources glycerol behaves differently in such a way that when glycerol concentration is higher than $2 \%$, the rhamnolipid level sharply decreases. Safi $e t a l^{28}$ reported that $3 \%$ glycerol produce only $2 \mathrm{~g} / \mathrm{L}$ rhamnolipids with fermentation. He also reported that $6 \%$ grape seed oil and sunflower oil also produce $2 \mathrm{~g} / \mathrm{L}$ of rhamnolipids. In case of $6 \%$ glucose, the rhamnolipid yield was found to be $1400-1500 \mathrm{mg} / \mathrm{l}$. It was also observed that 1.3 and $2.1 \mathrm{~g} / \mathrm{L}$ rhamnolipids were produced with $6 \%$ and 
$5 \%$ concentration of diesel and kerosene oil respectively ${ }^{2}$. Soybean lecithin and crude oil were also identified as suitable carbon sources for biosurfatant production. Changjun Zoua ${ }^{29}$ proved through his study that soybean lecithin was well utilized for biosurfactant production than crude oil with a slight difference. But crude oil also proved to be an efficient carbon source in case of Acenitobacter-related bacteria as reported by Huy et $a l^{30}$. The use of hydrocarbons such as n-hexadecane and paraffin were also were also attempted as carbon source by Jorge F.B. Pereira and found that only water soluble carbon sources could be easily utilized for biosurfactant production than paraffin and $n$-hexadecane ${ }^{31}$. However, Onwosi and Odibo ${ }^{31}$ suggested that glucose was the excellent carbon source at concentration of $2 \%$ for rhamnolipids production and the yield was $5.28 \mathrm{~g} / \mathrm{l}$.

\subsubsection{Effect of Nitrogen Source}

Nitrogen sources play a critical role in biomass growth and thereby the biosurfactant production. Pseudomonas aeruginosa was found to be a good strain for the production of biosurfactant. However due to the depletion of nitrogen source it reached the stationary phase which results in reduction of biosurfactant production $^{33}$. Excess of nitrogen source inhibited the biosurfactant producing microorganism hence the production of biosurfactant was found to be less ${ }^{34}$. Several nitrate salts such as sodium nitrate, ammonium nitrate, potassium nitrate was used as nitrogen sources for biosurfactant production and reported. Sodium nitrate was the good nitrogen source for biosurfactant production and the yield was found to be $4.38 \mathrm{~g} / \mathrm{l}^{32}$. According to Joshi and Shekhawat ${ }^{35}$, ammonium nitrate was supported as best nitrogen source for biosurfactant production. Similarly Johnson et $a l^{36}$ reported that potassium nitrate is the better nitrogen source for biosurfactant production by Rhodotorulaglutinis IIP-30 when compared to other nitrogen source such as ammonium sulphate or urea. As evaluated by Jorge F.B. Pereira, organic sources such as meat extract and yeast extract could also be efficiently utilized as nitrogen sources and found to affect the biosurfactant production ${ }^{31}$.

\subsubsection{Effect of Temperature}

Temperature is also one of the important factors for biosurfactant production. Rhamnolipid productions increased with temperature from 25 to $30^{\circ} \mathrm{C}$ and remain constant from 30 to $37^{\circ} \mathrm{C}$ and slightly decreased when the temperature reached $42^{\circ} \mathrm{C}$. Vollbrecht et al briefly studied the effect of temperature on the growth of Pseudomonas aeruginosa and rhamnolipid production. At higher temperature such as $47^{\circ} \mathrm{C}$ provided unfavourable condition for the culture growth and hence rhamnolipid production was found to be lesser. Similarly for Tsukamurella sp. culture, at higher temperature cell aggregation occurs which results in lower glycolipid production. However certain microorganisms such as Acinetobacter baylyi ZJ2 could withstand higher temperature $\left(40-45^{\circ} \mathrm{C}\right)$ was identified through the investigation carried out by Changjun Zoua. An optimum temperature of $30^{\circ} \mathrm{C}$ was suggested where cell growth was promoted and yielded a higher glycolipid production. Joice and Parthasarathi also showed that the highest biosurfactant production by Pseudomonas aeruginosa PBSCI was at the temperature of $30^{\circ} \mathrm{C}^{37,38 \text {, and } 31}$.

\subsubsection{Effect of $\mathrm{pH}$}

$\mathrm{pH}$ is another important factor which affects the biosurfactant production ${ }^{39}$. A pH range of 6.0-6.5 was found to be ambient for the biosurfactant production. At $\mathrm{pH}$ above 6.5 , the biosurfactant production was found to be decreased. At $\mathrm{pH} 4-4.5$, the bacterium was unable to reduce the surface tension of culture medium therefore yield of biosurfactant tends to decrease. Cooper and Goldenberg ${ }^{18}$ reported that an increase in $\mathrm{pH}$ from 6.5 to 7.0 has not decreased the growth of microorganism for biosurfactant production. However lowering the $\mathrm{pH}$ affected the biosurfactant production ${ }^{40}$. Similarly above $\mathrm{pH} 7$, the growth was retarded in an alkaline environment and was reported by Changjun Zoua while studying biosurfactant production using Acinetobacter baylyi $Z J J^{29}$. $\mathrm{pH}$ was found to affect the metabolism of microorganisms ${ }^{40}$. Joice and Parthasarathi ${ }^{37}$ studied the biosurfactant production by altering the $\mathrm{pH}$ from 5.0 to 8.5 and observed that surface tension reduction of 29.19 $\mathrm{mN} / \mathrm{m}$ at $\mathrm{pH} 6.5$ and emulsification activity was $75.12 \%$ at $\mathrm{pH} 7.0$. Joice and Parthasarathi ${ }^{37}$ concluded that biosurfactant production by Pseudomonas aeruginosa PBSC1 was maximum at $\mathrm{pH}$ 7.0.

\subsubsection{Effect of Aeration and Agitation}

Aeration is related to foam accumulation ${ }^{41}$. Agitation affects both mass transfer of oxygen and medium components. Hence aeration and agitation need to be considered an important factor for cell growth and biosurfactant production especially for aerobic organisms. Sen optimized the air flow rate using response surface method as $0.75 \mathrm{vvm}$ for biosurfactant production. Similarly the effect of agitation was studied and reported that an increase in agitation rate from 50 to $200 \mathrm{ppm}$ increased the growth rate from 0.2 to 0.72 / hour and a maximum biosurfactant yield of $80 \%$ could be achieved at this condition ${ }^{42}$. This is because the increase in agitation rate greatly affected the dissolved oxygen level in the system from 0.1 to $0.55 \mathrm{mg} / \mathrm{l}$. Hence at higher dissolved oxygen levels, the cell growth was greatly influenced and thereby higher biosurfactant production ${ }^{43}$. 


\section{Purification Methods for Biosurfactants}

In conventional methods, hydrochloric acid in concentrated form was used to extract crude biosurfactants from microbial biomass. However in the present stage, various techniques have been developed to isolate and purify crude biosurfactant such as membrane based techniques, foam fractionation, extraction, adsorption ${ }^{49}$. Membrane separation was first reported by Sen and Swaminathan ${ }^{49}$ for the recovery of surfactin. Presently the bubbleless membrane bioreactor has been successfully developed for biosurfactant production ${ }^{50}$. In bubbleless membrane bioreactor the microfiltration and ultrafiltration are coupled together to increase the efficiency of separation process. Foam fractionation is a method for the separation of biosurfactant where acidified hydrochloric acid is added to precipitate biosurfactant. The precipitates can be extracted with solvent ${ }^{51}$. Davis $e t a l^{52}$ reported that foam fractionation is an integrated system for the isolation of surfactin.

Nowadays extraction is gaining much attraction towards the researchers due to the easier operation. Various solvents such as chloroform, methanol, ethyl acetate, di-chloromethane, butanol, pentane, hexane, diethyl ether, isopropanol, acetic acid are used for the extraction of biosurfactant. In solvent extraction, hydrophobic moieties are found to be soluble in some solvents which help in extraction of crude product ${ }^{2}$. In adsorption and desorption process, the amberlite XAD 2 or polystyrene resins are used for purification of biosurfactants. During this process, the recovery of biosurfactant is governed by various factors such as agitation rate, activated carbon particle size, $\mathrm{pH}$, temperature, initial adsorbent concentration, amount of adsorbent and ionic strength. In newly developed techniques polymer resins are used to adsorb biosurfactant and for desorption, the organic solvents are used. The active carbon is used as an adsorbent for recovery of surfactin ${ }^{53}$. Further the regenerated activated carbon also can be used for the recovery of biosurfactants ${ }^{54}$.

\section{Analytical Methods}

Several analytical methods have been utilized and reported by many researchers in their analysis for characterisation of biosurfactant. Table 3 indicates the biosurfactant type, microorganisms, solvent and type of analytical method.

Table 3: Type of Biosurfactants, Bacteria, Solvent and Analytical Methods Involved

\begin{tabular}{|l|l|l|l|}
\hline Biosurfactant\& Bacteria & Analytical Method & Chemicals/Solvents required & Reference \\
\hline \multirow{2}{*}{$\begin{array}{l}\text { Rhamnolipids } \\
\text { Pseudomonas aeruginosa }\end{array}$} & $\mathrm{HPLC}$ & $\mathrm{CH}_{3} \mathrm{CN}-\mathrm{H}_{2} \mathrm{O}$ & 55 \\
\cline { 2 - 4 } & TLC & $\mathrm{CHCl}_{3} / \mathrm{CH}_{3} \mathrm{OH} / \mathrm{CH}_{3} \mathrm{COOH}$ & 56 \\
\cline { 2 - 4 } & TLC & $\mathrm{CH}_{3} \mathrm{OH} / \mathrm{H}_{2} \mathrm{O}$ & 57 \\
\hline Pseudomonas fluorescens & TLC & $\mathrm{CH}_{3} \mathrm{CN} / \mathrm{H}_{2} \mathrm{O}$ & 58 \\
\hline P. aeruginosa MTCC 2297 & HPLC & $\begin{array}{l}\mathrm{CH}_{3} \mathrm{CN} \text { (Contain 2- bromoacetophenone and } \\
\text { triethylamine) }\end{array}$ & 59 \\
\hline $\begin{array}{l}\text { Lipopeptide } \\
\text { Acinetobacter baylyi ZJ2 }\end{array}$ & FTIR & $\mathrm{CHCl}_{3} / \mathrm{CH}_{3} \mathrm{OH} / \mathrm{CH}_{3} \mathrm{COOH}$ & 60 \\
\hline $\begin{array}{l}\text { Sophorolipid } \\
\text { Candida bombicola }\end{array}$ & HPLC with ELSD & $\mathrm{CH}_{3} \mathrm{CN}_{2} \mathrm{O}$ & 61 \\
\hline $\begin{array}{l}\text { Phospholipid } \\
\text { Acinetobacter sp. }\end{array}$ & GC-MS & $\mathrm{CHCl}_{3} / \mathrm{CH} 3 \mathrm{OH}$ (Extraction Method) & 62 \\
\hline $\begin{array}{l}\text { Trehalose lipid } \\
\text { Rhodococcus sp. P32C1 }\end{array}$ & HPLC & $\mathrm{CH}_{3} \mathrm{CN}$ & 63 \\
\hline $\begin{array}{l}\text { Surfactin } \\
\text { Bacillus Subtilis ATCC } 21332\end{array}$ & HPLC & $\mathrm{CH}_{3} \mathrm{CN} / \mathrm{TFA}$ & 64 \\
\hline
\end{tabular}

\section{Application of Biosurfactants}

\section{Biosurfactants in Metallurgical Industry}

Nowadays, various pollutants are released in to the environment due to vast industrialization. One of such pollutants is heavy metals released from metallurgical industries. Heavy metal being a toxic pollutant contaminates soil, water and seems to get accumulated into food chain. Heavy metals are persistent in nature and cause serious environmental issues. Techniques such as excavation have been reported to clean up the soil contaminated with heavy metal and disposal of contaminated soil to the land sites ${ }^{65}$.

In bioreduction of these heavy metals, Microbes can be used as a whole cell biocatalyst to transform the metal into various states ${ }^{66}$. Soil washing and soil flushing is well known bioremediation method to treat heavy metal contaminated soil using biosurfactants. . In an in-situ bioremediation, the biosurfactant are charged on the soil using the drain pipes and trenches ${ }^{67}$. However in ex-situ, the soil is collected from the location and transported to wash column and washed with biosurfactant solution. Biosurfactant could greatly improve the solubility of heavy metals at high concentration and critical micelle concentration. A strong ionic bond is developed between positively charged metal and negatively charged surfactants and finally a surfactant-metal complex is formed. By lowering the surface tension the metal-biosurfactant complex is desorbed from the soil. Generally the solubilisation of metals using biosurfactant is referred to as bioleaching, a process describes as dissolution of metals from mineral source by certain naturally occurring microorganism or from their products. 
Biosurfactant converts solid metal into soluble form. The mechanisms such as binding, complexation, desorption and precipitation may found to occur in the removal of heavy metals. Precipitation of heavy metals in water has been practiced as an important method of treatment in industrial wastewater for many years. A combined method of biosurfactant precipitation with chemical treatment techniques such as ion exchange has been reported to be effective in heavy metal removal.

Di-rhamnolipids produced from Pseudomonas aeruginosa have been used in the immobilisation of metals from multi-metal contaminated soil ${ }^{68}$. They are also used in the removal of various heavy metals such as chromium, lead, cadmium and copper from soil. Marine biosurfactants are typical type of biosurfactants isolated from marine bacterium used in the remediation of polyaromatic hydrocarbon ${ }^{69}$. However no study report is found for heavy metal remediation. The biosurfactant synthesized from marine organism has the capability to chelate toxic heavy metals. Therefore it is used in the treatment of heavy metal containing waste water. Addition of alkali enhances removal of heavy metals ${ }^{70}$. Foam technology is another advancement method in the biosurfactant based bioremediation. Wang and Mulligan investigated the performance of rhamnolipids to remove $\mathrm{Cd}$ and $\mathrm{Ni}$ from sandy soil. Generally the foam formed flows into a porous medium and made more uniform and hence makes an efficient contact with metals. The bare rhamnolipid solution used in the removal of $\mathrm{Cd}$ and $\mathrm{Ni}$ has an efficiency of $61.7 \%$ and $51 \%$. But rhamnolipid coupled with foam found to enhance the efficiency of $\mathrm{Cd}$ and $\mathrm{Ni}$ removal with $73.2 \%$ and $68.1 \%{ }^{71}$. Massara $e$ t $a l^{72}$ investigated on the removal of $\mathrm{Cr}$ (III) from kaolinite contaminated with chromium. The factors such as $\mathrm{pH}$ and addition of $\mathrm{NaOH}$ could positively affect the metal removal. The chelating action of biosurfactants was greatly enhanced by $\mathrm{pH}$ and hence higher metal removal. The addition of $\mathrm{NaOH}$ increase the biosurfactant solubility thereby promotes better metal removal $^{47}$. The removal of heavy metals reported by different authors is shown in Table 4 .

Table 4: Removal of Heavy Metals by Biosurfactant Producing Organism

\begin{tabular}{|l|l|l|l|l|}
\hline S.NO & Metals & Microorganism & Removal (\%) & Reference \\
\hline \multirow{2}{*}{1.} & \multirow{2}{*}{$\mathrm{Cr}$} & Pseudomonas aeruginosa & 46 & 73 \\
\cline { 3 - 5 } & & Aspergillus niger & $21-36$ & 74 \\
\hline \multirow{2}{*}{2.} & \multirow{2}{*}{$\mathrm{Od}$} & Bacillus strain $\mathrm{H} 9$ & 36 & 75 \\
\cline { 3 - 5 } & & Aspergillusterreus & 70 & 76 \\
\cline { 3 - 5 } & \multirow{2}{*}{3.} & Pseudomonas aeruginosa & 73.2 & 71 \\
\hline \multirow{2}{*}{4.} & \multirow{2}{*}{$\mathrm{Pb}$} & Thiobacillus ferrooxidans & 25 & 77 \\
\cline { 3 - 5 } & & Schizosaccharomyces pombe & $11-25$ & 78 \\
\hline \multirow{2}{*}{5.} & \multirow{2}{*}{$\mathrm{Ni}$} & Pseudomonas aeruginosa PU21 & 80 & 79 \\
\cline { 3 - 5 } & & Pseudomonas spp. & $13-88$ & 74 \\
\cline { 3 - 5 } & & Candida spp & 98 & 71 \\
\cline { 3 - 5 } & & Pseudomonas aeruginosa & 68.1 & 87 \\
\hline
\end{tabular}

\section{Biosurfactants in Petroleum Industry}

Biosurfactant producing organisms (indigenous or injected) are exploited in oil recovery in oil producing wells. By direct injection of nutrients with microbes that are capable of producing desired products for mobilization of oil, by injection of a specific microorganism or injecting biosurfactants through this method, the microbial enhanced oil recovery process is implemented. Interfacial reduction of tension/oil viscosity, reservoir repressurizations are followed by this process. By injection of biosurfactants, bacteria such as Pseudomonas aeruginosa, Bacillus licheniformis and nutrients, the oil recovery was showed to be increased by $30-200 \%{ }^{82}$. Microbial enhanced oil recovery is the best method to recover oil from high viscosity crude oil or from reservoirs with low permeability. Oil field emulsions are one of the major problems for the petroleum industry. It occurs at various stages while processing the crude oil. To control oil field emulsion, the deemulsification process is one of the best methods to recover oil from these emulsions. A conventional deemulsification process is obtained by centrifugation, heat treatment and chemicals. Biosurfactants have the ability to retrieve the use of chemical de-emulsifier insitu and it can provide eco-friendly solution. Some of the bacterial species such as Acinetobacter and Pseudomonas species are the main de-emulsifiers in the mixed cultures $^{83}$. To disrupt the emulsion, the microorganisms exploit the amphiphilic nature of biosurfactants or hydrophobic cell surface. The classes of biosurfactants such as glycolipids, glycoproteins, phospholipids and polysaccharides are the microbial tools to displace the emulsifiers from the oil- water interface ${ }^{1}$. Biosurfactants having potential application to recover oil from petroleum tank bottom sludges and facilitates heavy crude transports through pipelines. From the used oil sorbents the soaked oil can be removed with the help of rhamnolipids $^{43}$. Main factors such as sorbent pore size and washing time are affecting the oil removal. By using the commercial rhamnolipids $95 \%$ oil removal was achieved. Apart from using crude biosurfactant, the application of fermentation broth could effectively remove crude oil from contaminated sites as well as motor oil by $85 \%$ and $90 \%$ repectively ${ }^{47}$. The rate of oil recovery reported by different authors is shown in Table 5 . 
Table 5: Recovery of oil by Biosurfactant Producing Organism

\begin{tabular}{|l|l|l|l|l|l|}
\hline S.No & $\begin{array}{l}\text { Biosurfactants Producing } \\
\text { Organism }\end{array}$ & Biosurfactants & Biosurfactant yield & $\begin{array}{l}\text { Recovery of Oil from Oil } \\
\text { Contaminated Soil (\%) }\end{array}$ & Reference \\
\hline $\mathbf{1 .}$ & Bacillus subtilis CN2 & Lipopeptide & $7150 \mathrm{mg} / 1$ & $84.6 \pm 7.1$ & 84 \\
\hline $\mathbf{2 .}$ & Bacillus subtilis BS-37 & Surfactin isoform & $585 \mathrm{mg} / 1$ & 96 & 85 \\
\hline $\mathbf{3 .}$ & Bacillus strain & & $\begin{array}{l}\text { Crude BS 0.081-1 g/l } \\
\text { CMC Value19.439mg/l }\end{array}$ & $30.22-34.19$ & 86 \\
\hline $\mathbf{4 .}$ & Bacillus subtilis B 30 & Surfactin & $\begin{array}{l}\text { Crude BS } \\
0.3-0.5 \mathrm{~g} / 1 \\
\text { CMC Value } 1: 8\end{array}$ & $17-26$ & 87 \\
\hline $\mathbf{5 .}$ & Candida sphaerica & $\begin{array}{l}\text { Anionic } \\
\text { biosurfactants }\end{array}$ & $4.5 \mathrm{~g} / 1$ & $\begin{array}{l}75 \text { (Clay soil) } \\
92 \text { (Silty Soil) }\end{array}$ & 88 \\
\hline $\mathbf{6 .}$ & Candida tropicalis & & $3.61 \pm 2.1$ & $78-97$ & 89 \\
\hline $\mathbf{7 .}$ & Candida glabrata UCP 1002 & & $7.52 \mathrm{~g} / 1$ & 92.6 & 90 \\
\hline $\mathbf{8 .}$ & Candida sphaerica UCP 0995 & $\begin{array}{l}\text { Biosurfactant } \\
\text { Lunasan }\end{array}$ & $9 \mathrm{~g} / 1$ & 95 & 91 \\
\hline
\end{tabular}

\section{Conclusion}

In this review paper, the various perspectives of biosurfactants are consolidated into fine and simple concepts for the readers to understand easily. In general, this paper summarizes the need of biosurfactants for the environmental application to harness the eco-friendly natural process and to catalyze the production rate. The indepth study has led to the development of various strains for the large scale production of biosurfactant and some of the screening techniques have been included for identifying the BS producers. Various operational parameters affecting the production process are also well explained. Analytical techniques such as HPLC, TLC, GC-MS, foam fractionation, membrane separation etc. were discussed briefly for the purification of the product. Various operational parameters affecting the production process are also well explained. Finally, in the application part, the role of biosurfactant in oil and metal related industries are also discussed.

\section{References}

[1] Mukherjee S, Das P \& Sen R, Towards commercial production of microbial surfactants, Trend Biotechnol, 24, 2006, 509-515.

[2] Desai J D \& Banat I M, Microbial production of surfactants and their commercial potential, Microbiol Mol Biol Rev, 61, 1997, 4764.

[3] Jarvis F G \& Johnson M J, A glyco-lipid produced by Pseudomonas aeruginosa, J Am Chem Soc, 71, 1949, 4124-4126

[4] Mulligan C N \& Gibbs B F, Types, Production and Applications of biosurfactants, Proc Indian natn Sci Acad, 70, $2004,31-55$.

[5] Rosenberg E \& Ron E Z, High and low molecular mass microbial surfactants, Appl Microbiol Biotechnol, 52, 1999, 154-162.

[6] Hommel R \& Ratledge C, Evidence for two fatty alcohol oxidases in the biosurfactant producing yeast Candida (Torulopsis) bomicola, FEMS Microbiol Lett, 70, 1990, 183-186.

[7] Britton L N, Microbial degradation of aliphatic hydrocarbons, in microbial degradation of organic compound, edited by D. T. Gibson, (Marcel Dekker, New York, 1984) 89-131.

[8] Leahy J G \& Colwell R R, Microbial degradation of hydrocarbons in the environment, Microbiol Rev, 54, 1990, 305-315.

[9] Singer M E, Finnerty W R, Microbial metabolism of straight-chain and branched alkanes, in Petroleum microbiology edited by Atlas R M, (Macmillan Publishing Company, New York,1984) 1-59.

[10] Ron E Z \& Rosenberg E, Biosurfactants and oil bioremediation, Cur Opin Biotechnol, 13, 2002, $249-252$.

[11] Morikawa M, Ito M \& Imanaka T, Isolation of new surfactin producer Bacillus pumilus A-1, and cloning and nucleotide sequence of the regulator gene psf-1, J Ferm Bioeng, 74, 1992, 255-261.

[12] Siegmund I \& Wagner F, New method for detecting rhamnolipids excreted by Pseudomonas sp during growth on mineral agar, Biotechnol Tech, 5, 1991, 265-268.

[13] Banat I M, The isolation of a thermophilic biosurfactant producing Bacillus sp, Biotechnol Lett, 15, 1993, $591-594$.

[14] Bodour A A \& Miller-Maier R, Application of a modified drops collapse technique for surfactant quantitation and screening of biosurfactant producing microorganism, J Microbiol Methods, 32, 1998, 273-280.

[15] Satpute S K, Bhawsar B D, Dhakephalkar P K \& Chopade B A, Assessment of different screening methods for selecting biosurfactant producing marine bacteria, Indian J Marine Sci, 37, 2008, 243-250.

[16] Rosenberg E, Zuckerberg A, Rubinovitz C \& Gutnick D L, Emulsifier of Arthrobacter RAG-1: isolation and emulsifying properties, Appl Environ Microbiol, 37, 1979, 402-408.

[17] Neu T R \& Poralla K, Emulsifying agent from bacteria isolated during screening for cells with hydrophobic surfaces, Appl Microbiol Biotechnol, 32, 1990, 521-525.

[18] Cooper D G \& Goldenberg B G, Surface-Active agents from two Bacillus species, Appl Environ Microbiol, 53, 1987, $224-229$.

[19] Ellaiah P, Prabhakar T, Sreekanth M, Taleb A T, Raju P B et al, Production of glycolipids containing biosurfactant by Pseudomonas species, Indian J Exp Biol, 40, 2002, 1083-1086.

[20] Benincasa M, Rhamnolipid produced from agro industrial wastes enhances hydrocarbon bidegradation in contaminated soil, Curr Microbiol, 54, 2007, 445-449.

[21] Lee K M, Hwang S, Ha S D, Jang J, Lim D et al, Rhamnolipid production in batch and fed-batch fermentation using Pseudomonas aeruginosa BYK-2 KCTC 18012P, Biotechnol Bioprocess Eng, 9, 2004, 267-273.

[22] Camilios-Neto D, Bugay C, De Santana-Filho A P, Joslin T, De Souza L M et al, Production of rhamnolipids in solid state cultivation using a mixture of sugarcane bagasse and corn bran supplemented with glycerol and soyabean oil, Appl Microbiol Biotechnol, 89, 2011, 1395-1403.

[23] Cooper D G, Macdonald C R, Duff S J \& Kosaric N, Enhanced production of surfactin from Bacillus subtilis by continuous product removal and metal cation additions, Appl. Environ Microbiol, 42, 1981, 408-412.

[24] Noah K S, Bruhn D F \& Bala G A, Surfactin production from potato process effluent by Bacillus subtilis in a chemostat, in Proc Twenty-Sixth Symp Biotechnol Fuels Chemicals (Chattanooga, TN, 2005) 465-473 
[25] Yeh M S, Wei Y H \& Chang J S, Bioreactor design for enhanced carrier-assisted surfactin production with Bacillus subtilis, Process Biochem, 41, 2006, 1799-1805.

[26] Coutte F, Lecouturier D, Yahia S A, Leclere V, Bechet P et al, Production of surfactin and fengycin by Bacillus subtilis in a bubbleless membrane bioreactor, Appl Microbiol Biotechnol, 87, 2010, 499-507.

[27] Robert M, Mercade M E, Bosch M P, Parra J L, Espuny M J et al, Effect of the carbon source on the biosurfactant production by $P$. aeruginosa 44T, Biotechnol Lett, 11,1989, 871-874.

[28] Safi A M, Gilherme Sasa Ki L, Lauro M, De souza, Joel Meira A et al, Molecular structural characterization of the biosurfactant produced by Pseudomonas aeruginosa DAUPE614, Chem and Physics of lipids, 147, 2007, 1-13.

[29] Changjun Zoua, Meng Wanga, Yu Xingb, Guihong Lana, Tingting Gea et al, Characterization and optimization of biosurfactants produced by Acinetobacter baylyi ZJ2 isolated from crude oil-contaminated soil sample toward microbial enhanced oil recovery applications, Biochem Eng J, 90, 2014, 49-58.

[30] N.Q. Huy, S. Jin, K. Amada, M. Haruki, N.B. Huu et al, Characterization of petroleum-degrading bacteria from oil-contaminated sites in Vietnam, J. Biosci. Bioeng, 88, 1999, 100-102.

[31] Jorge F.B Pereira, Eduardo J. Gudina, Rita Costa, Rui Vitorina, Jose A. Teixeira et al, Optimization and characterization of biosurfactant production by Bacillus subtilis isolates towards microbial enhanced oil recovery applications, Fuel, 113, 2013, 259268.

[32] Onwosi C O \& Odibo F J C, Effect of carbon and nitrogen sources on rhamnolipid biosurfactant production by Pseudomonas nitroreducens isolated from soil, World J Microbiol Biotechnol, 28, 2012, 937-942.

[33] Ramana K V \& Karanth N G, Factors affecting biosurfactant production using Pseudomonas aeruginosa CFTR-6 under submerged conditions, J Chem Technol Biotechnol, 45, 1989, 249-257.

[34] Syldatk C, Lang S, Wagner F, Wray V \& Witte L, Chemical and physical characterization of four interfacial-active rhamnolipids from Pseudomonas spec. DSM 2874 grown on n-alkanes, Z Naturforsch C, 40, 1985, 51-60.

[35] Joshi P A \& Shekhawat D B, Effect of carbon and nitrogen source on biosurfactant production by biosurfactant producing bacteria isolated from petroleum contaminated site, Adv Appl Sci Res, 5, 2014, 159-164.

[36] Johnson V, Singh M \& Saini V S, Bioemulsifier production by an oleaginous yeast Rhodotorula glutinis IIP-30, Biotechnol Lett, 14, 1992, 487-490.

[37] Joice P A \& Parthasarathi R, Optimisation of biosurfactant production from Pseudomonas aeruginosa PBSC1, Int J Curr Microbiol App Sci, 3, 2014, 140-151.

[38] Vollbrecht E, Heckmann R, Wray V, Nimtz M \& Lang S, Production and structure elucidation of di- and oligosaccharide lipids (biosurfactants) from Tsukamurella sp. nov, Appl Microbiol Biotechnol, 50, 1998, 530-537.

[39] Gobbert U, Lang S \& Wagner F, Sophorose lipid formation by resting cells of Torulopsis bombicola, Biotechnol Lett, 6, 1984, 225230 .

[40] Guerra-Santos L H, Kappeli O \& Fletcher A, Dependence of Pseudomonas aeruginosa continuous culture biosurfactant production on nutritional and environmental factors. Appl Microbiol Biotechnol, 24, 1986, 225-230.

[41] Shaligram N S \& Singhal R S, Surfactin-A review on biosynthesis, fermentation, purification and applications. Food Technol Biotechnol, 48, 2010, 119-134.

[42] Sen R, Response surface optimization of the critical media components for the production of surfactin, J Chem Technol Biotechnol, $68,1997,263-270$.

[43] Wei Y H, Chien L C \& Chang J S, Rhamnolipid production by indigeneous Pseudomonas aeruginosa J4 originating from petrochemicals wastes, Biochem Eng J, 27, 2005, 146-154.

[44] Mouafi F E, Abo Elsoud M M \& Moharam M E, Optimization of biosurfactant production by Bacillus brevis using response surface methodology, Biotechnol Rep, 9, 2016, 31-37.

[45] Velioglu Z \& Urek R O, Optimization of cultural conditions for biosurfactant production by Pleurotus djamor in solid state fermentation, J Biosci Bioeng, 120, 2015, 526-531.

[46] Deepika K V, Klam S, Sridhar R, Podile A R \& Bramhachari P V, Optimization of rhamnolipid biosurfactant production by mangrove sediment bacterium Pseudomonas aeruginosa KVD-HR42 using response surface methodology, Biocatal Agric Biotechnol, 5, 2016, 38-47.

[47] Lima de Franc I W, Parente Lima A, Monteiro Lemos J A, Farias Lemos C G, Maciel Melo V M et al, Production of a biosurfactant by Bacillus subtilis ICA56 aiming bioremediation of impacted soils, Catal Today, 255, 2015, 10-15

[48] Patil S, Pendse A \& Aruna K, Studies on optimization of biosurfactant production by Pseudomonas aeruginosa F23 isolated from oil contaminated soil sample, Int J Curr Biotechnol, 2, 2014, 20-30

[49] Sen R \& Swaminathan T, Characterization of concentration and purification parameters and operating conditions for the small scale recovery of surfactin, Process Biochem, 40, 2005, 2953-2958.

[50] Coutte F, Lecouturier D, Leclere V, Bechet M, Jacques P et al, New integrated bioprocess for the continuous production, extraction and purification of lipopeptides produced by Bacillus subtilis in membrane bioreactor, Process Biochem, 48, 2013, 25-32.

[51] Cooper D G, Macdonald C R, Duff S J \& Kosaric, Enhanced production of surfactin from Bacillus subtilis by continuous product removal and metal cation additions, Appl Environ Microbiol, 42, 1981, 408-412.

[52] Davis D A, Lynch H C \& Varley J, The application of foaming for the recovery of surfactin from Bacillus subtilis ATCC 21332 cultures, Enzyme Microb Technol, 28, 2001, 346-354.

[53] Liu T, Montastruc L, Gancel F, Zhao L \& Nikov I, Integrated process for production of surfactin: part 1: adsorption rate of pure surfactin onto activated carbon, Biochem Eng J, 35, 2007, 333-340.

[54] Dubey K V, Juwarkar A A \& Singh S K, Adsorption-desorption process using wood based activated carbon for recovery of biosurfactant from fermented distillery waste water, Biotechnol Prog, 21, 2005, 860-867.

[55] Schenk T, Schuphan I \& Schmidt B, High performance liquid chromatographic determination of rhamnolipid produced by Pseudomonas aeruginosa, J Chromat A, 693, 1995, 7-13.

[56] Arino S, Marchal R \& Vandecasteele J, Identification and production of rhamnolipidic biosurfactant by Pseudomonas sp, Appl Microbiol Biotechnol, 45, 1996, 162-168.

[57] Rahman K S M, Vasudevan N \& Lakshmanaperumalsamy P, Enhancement of biosurfactant production to emulsify different hydrocarbon, J Environ Poll, 6, 1999, 87-93.

[58] Caldini G, Cenci G, Manenti R \& Morozzi G, The ability of an environmental isolate of Pseudomonas fluorescens to utilize chrysene and other four-ring polynuclear aromatic hydrocarbons, Appl Microbiol Biotechnol, 44, 1995, 225-229.

[59] Venkatesh N \& Vedaraman N, Remediation of soil contaminated with copper using rhamnolipids produced from Pseudomonas aeruginosa MTCC 2297 using waste frying rice bran oil, Ann Microbiol, 62, 2012, 85-91. 
[60] Zou C, Wang M, Xing Y, Lan G, Ge T et al., Characterization and optimization of biosurfactants produced by Acinetobacter baylyi ZJ2 isolated from crude oil- contaminated soil sample toward microbial enhanced oil recovery applications, Biochem Eng $J$, 90 , 2014, 49-58

[61] Davila A M, Marchel R, \& Vandecasteele J P, Sophorose lipid fermentation with differentiated substrate supply for growth and production phase, Appl Microbiol Biotechnol, 47, 1997, 496-501.

[62] Koma D, Hasumi F, Yamamoto E, Ohta T, Chung S-T et al., Biodegradation of long-chain n-paraffins from waste oil of car engine by Acinetobacter sp, J Biosci Bioeng, 91, 2001, 157-170.

[63] Maghsoudi S, Vossoughi M, Kheirolomoom A, Tanaka E \& Katoh S, Biodesulfurisation of hydrocarbons and diesel fuels by Rhodococcus sp strain P32CI, Biochem Eng J, 8, 2001, 151-156.

[64] Davis D A, lynch H C \& Varley J, The application of foaming for the recovery of surfactin from Bacillus subtilis ATCC 21332 cultures, Enzyme Microb Technol, 28, 2001, 346-354.

[65] Asci Y, Nurbas M \& Acikel Y S, Investigation of sorption/desorption equilibria of heavy metal ions on/from quartz using rhamnolipid biosurfactant, J Environ Manage, 91, 2010, 724-731.

[66] Bruins M R, Kapil S \& Oehme F W, Microbial resistance to metals in the environment, Ecotoxicol Environ Saf, 45, $2000,198-207$.

[67] Singh P \& Cameotra S S, Enhancement of metal bioremediation by use of microbial surfactants, Biochem Biophy Res Commun, 319, 2004, 291-297.

[68] Juwarkar A A, Dubey K V, Nair A \& Singh S K, Bioremediation of multi-metal contaminated soil using biosurfactant-a novel approach, Indian J Microbiol, 48, 2008, 142-146.

[69] Das P, Mukherjee S \& Sen R, Biosurfactant of marine origin exhibiting heavy metal remediation properties, Bioresour Technol, $100,2009,4887-4890$.

[70] Singh P \& Cameotra S S, Emnhancement of metal bioremediation by use of microbial surfactants, Biochem Biophy Res Commun, 319, 2004, 291-297.

[71] Wang S \& Mulligan C N, Rhamnolipid foam enhanced remediation of cadmium and nickel contaminated soil, Water Air Soil Pollut, 157, 2004, 315-330.

[72] Massara H, Mulligan C N \& Hadjinicolaou J, Effect of rhamnolipids on chromium contaminated soil, Soil Sediment Cont Int J, 16, 2007, 1-14.

[73] Hassen A, Saidi N, Cherif M \& Boudabous A, Effect of heavy metals on Pseudomonas aeruginosa and Bacillus thuringiensis, Bioresour Technol, 65, 1998, 73-82.

[74] Dursun A Y, Ulsu G, Cuci Y \& Aksu Z, Bioaccumulation of copper (II), lead (II) and chromium (VI) by growing Aspergillus niger, Process Biochem, 38, 2003, 1647-1651.

[75] Roane T M, Josephson K L \& Pepper I L, Dual-bioaugmentation strategy to enhance remediation of contaminated soil, Appl Environ Microbiol, 67, 2001, 3208-3215.

[76] Massaccesi G, Romero M C, Cazau M C \& Bucsinszky A M, Cadmium removal capacities of filamentous soil fungi isolated from industrially polluted sediments, in La Plata (Argentina), World J Microbiol Biotechnol, 18, 2002, 817-820.

[77] Boyer A, Magnin J-P \& Ozil P, Copper ion removal by Thiobacillus ferrooxidans biomass, Biotechnol Lett, 20, 1998, 187-190.

[78] Donmez G \& Aksu Z, The effect of copper (II) ions on growth and bioaccumulation properties of some yeasts, Process Biochem, 35, 1999, 135-42.

[79] Chang J O, Law R \& Chang C C, Biosorption of lead, copper and cadmium by biomass of Pseudomonas aeruginosa PU21, Water Res, 31, 1997, 1651-1658.

[80] Magyarosy A, Laidlaw R D, Kilaas R, Echer C, Clark D S et al, Nickel accumulation and nickel oxalate precipitation by Aspergillus niger, Appl Microbiol Biotechnol, 59, 2002, 382-388.

[81] Donmez G \& Aksu Z, Bioaccumulation of copper (II) and nickel (II) by the non-adapted growing Candida sp, Water Res, 35, 2001, $1425-1434$.

[82] Singh S, Kang S H, Mulchandani A \& Chen W, Bioremediation: environmental clean-up through pathway engineering, Curr Opin Biotechnol, 19, 2008, 437-444.

[83] Nadarajah N, Singh A \& Ward O P, De-emulsification of petroleum oil emulsion by a mixed bacterial culture, Process Biochem, 37, 2002, 1135-1141.

[84] Bezza F A \& Chirwa E M N, Production and application of lipopeptide biosurfactant for bioremediation and oil recovery by Bacillus subtilis CN2, Biochem Eng J, 101, 2015, 168-178.

[85] Liu Q, Lin J, Wang W, Huang H \& Li S, Production of surfactin isoforms by Bacillus subtilis BS-37 and its applicability to enhanced oil recovery under laboratory conditions, Biochem Eng J, 93, 2015, 31-37.

[86] Joshi S J \& Desai A J, Bench-scale production of biosurfactants and their potential in ex-situ MEOR application, Soil Sediment Contam, 22, 2013, 701-715.

[87] Al-Wahaibi Y, Joshi S, Al-Bahry S, Elshafie A, Al-Bemani A et al, Biosurfactant production by Bacillus subtilis B30 and its application in enhancing oil recovery, Colloids Surf B, 114, 2014, 324-333.

[88] Sobrinho H B S, Rufino R D, Luna J M, Salgueiro A A, Campo-Takaki G M et al, Utilization of two agroindustrial by-products for the production of a surfactant by Candida sphaerica UCP0995, Process Biochem, 43, 2008, 912-917.

[89] Batista R M, Rufino R D, Luna J M, De Souza J G \& Sarubbo L A, Effect of medium components on the production of biosurfactant from Candida tropicalis applied to the removal of hydrophobic contaminants in soil. Water Environ Res, 82, 2010, 418-425.

[90] Gusmao C A B, Rufino R D \& Sarubbo L A, Laboratory production and characterization of a new biosurfactant from Candida glabrata UCP 1002 cultivated in vegetable fat waste applied to the removal of hydrophobic contaminant. World J Microbiol Biotechnol, 26, 2010, 1683-1692.

[91] Luna J M, Rufino R D, Sarubbo L A, Rodrigues L R M, Teixeira J A C et al, Evaluation of the antimicrobial and antiadhesive properties of biosurfactant lunasan produced by Candida sphaerica UCP 0995, Curr Microbiol, 62, 2011, $1527-1534$. 